\title{
Effects of Problem-solving Strategies in the Teaching and Learning of Engineering Drawing Subject
}

\author{
Ruhizan M. Yasin ${ }^{1}$, Lilia Halim¹ \& Azaman Ishar $^{1}$ \\ ${ }^{1}$ Faculty of Education, Universiti Kebangsaan Malaysia, Selangor, Malaysia \\ Correspondence: Ruhizan M. Yasin, Faculty of Education, Universiti Kebangsaan Malaysia, 43600 UKM Bangi, \\ Selangor, Malaysia. Tel: 60-3-8921-6275. E-mail: dr_ruhizan@yahoo.com
}

Received: September 20, 2012 Accepted: November 7, 2012 Online Published: November 30, 2012

doi:10.5539/ass.v8n16p65

URL: http://dx.doi.org/10.5539/ass.v8n16p65

\begin{abstract}
The objective of this paper is to discuss the effects of teaching problem-solving strategies in the Engineering Drawing (ED) subject on student achievement, students' knowledge of problem-solving and students' problem-solving skills. The study was conducted on Form Four students (16 year old) from two Technical Secondary Schools in Peninsular Malaysia using two research instruments: the ED performance test and a questionnaire on problem-solving strategies. The quasi-experimental research design was employed on a sample of 209 students. The experimental group of 110 student utilized ED module which incorporated problem-solving strategies, while the control group of 109 student went through a conventional teaching and learning method. Research results showed that there were significant differences in terms of student achievement and student knowledge of problem-solving: the mean score of the experimental group was higher compared to that of the control group. On the other hand, research results showed that there was no significant difference between the two groups in terms of students' problem-solving skills, but the mean score of the experimental group was higher compared to that of the control group. This proves that the implementation of problem-solving strategies in teaching and learning successfully increases student achievement and students' knowledge of problem-solving besides positively affecting students' problem-solving skills. Therefore, teachers are advised to incorporate problem-solving strategies in their teaching and learning, especially in the Engineering Drawing subject.
\end{abstract}

Keywords: problem-solving strategies, knowledge of problem-solving, problem-solving skills, engineering drawing

\section{Introduction}

Problem-solving strategy is a method that can potentially produce effective and meaningful teaching and learning (T\&L) as it is a strategy that is applied experientially and is student-centric. According to Serap and Gamze (2010), problem-solving strategies are significantly linked to the elements involved in problem-solving procedures. Weinstein and Mayer (1986) state that a few cognitive psychologists define 'problem-solving strategies' as cognitive or learning strategies, while other cognitive psychologists define it from the standpoint of internal metacognitive processes such as high-level thinking, metacognition, metacognitive strategies, or self-control strategies (Armour-Thomas et al, 1992). On the other hand, Mayer (1983) generally defined problem-solving strategies as a route that does not necessarily provide a definite correct result, but is instead a guide to help students solve problems. The application of this strategy in T\&L can help improve students' problem-solving skills as problem-solving is a basic skill needed by all students, but at the same time, can also be a complex mental activity (Charles et al. 1997). According to Munir (2008) and Oguz (2011), the implementation of problem-solving in the T\&L environment can improve the quality of learning. Through these strategies, students have to find information and solve problems through their own efforts; this process compels them to be independent and to think critically and creatively (Sarimah \& Abreza 2010). Problem solving is known as one of the essence in building future engineers and technologies (Felders, 1988, Jonessen et al, 2006). They are people who make our life easier, healthier and safer through new designs and technologies. Problem solving can be taught in many ways in Engineering Education programmes, but the most important thing is the problem should be a real world problem. Designing is part of the important elements in engineering which being taught through engineering drawing (ED) subject.

Engineering Drawing consists of geometrical and technical rules or drawing convention and visual skills (Olkun, 
2003). It is a means of graphical communication engineers and technologist used in their process of designing. Before they started designing anything, they should be able to translate the problem under study into a pictorial representation. This can be done through incorporating problem solving strategies in Engineering Drawing teaching and learning. Students whom are skilled at Engineering Drawing are usually proficient at understanding concepts and theories, are able to master certain skills, and can solve ED problems well. Why do some students find it difficult to apply the skills and concepts that they learn in ED? Why is ED considered a difficult subject by some students? This is due to ED's essentially hierarchical design; a student's understanding of one concept is dependent on his understanding of another. A student's failure to understand the basic concepts of ED will make learning at the next level more challenging (Abd. Hadi 2005, Mohd. Safarin 2008). What are the criteria used by a student in learning ED? To a student, obtaining information in ED is an arduous procedure because it involves cognitive and psychomotor procedures which require them to be skilled in problem-solving. According to Schoenfeld (1994), problem-solving is a complex process that engages various cognitive operations such as collecting and sorting information, and heuristic and metacognititve strategies. Most students are not actually weak in problem-solving, but rather are unskilled in planning strategies when solving a given problem (Schoenfeld 1985 and Zan 2000). Students' failure in ED is actually a reflection of their failure in problem-solving; therefore, problem-solving is important in the learning of ED.

A research conducted by Berinderjeet (1997) found that students fail in solving problems due to a few factors i.e. low understanding of the given problem, low knowledge of how to plan an appropriate problem-solving strategy, inability to interpret a problem, application of inappropriate strategy, committing mistakes during the exchange of information, mistakes during computation, poor understanding of concepts, and confusion in the interpretation of information. According to İbrahim and Erol (2005), problem-solving skills among students can be improved by providing them with appropriate $T \& \mathrm{~L}$ support by integrating problem-solving strategies in the T\&L support material.

The exposure to problem-solving strategies that students receive can help them improve their achievement, increase their interest in a subject, and change student attitudes towards learning (Gök, T. \& Silay 2010). According to Taconis et al. (2001), problem-solving strategies can be taught and learned. The goal of the application of problem-solving strategies in T\&L is to give students a chance to use the skills they have learned in tackling relevant problems (Shahabuddin et al. 2007). According to PPK (2003), problem-solving can be integrated into all learning activities for students of all levels of achievement and it can also be taught at any level of T\&L. The main point is for the T\&L to be conducted actively i.e. problem-solving as a hands-on and minds-on activity. Problem-solving strategies can be taught in several ways: teachers can teach it by discussing problems with students, or by displaying or showing the correct answer or solution during T\&L in class (Reif 1981). According to Tan \& Lee (1999), problem-solving can be taught by showing students how a problem is solved. The students' role is to observe and analyze the steps taken by the teacher in solving the problem and then to apply the same strategies in solving other relevant problems. Besides that, teachers can also encourage students to perform rote-learning where students are asked to solve as many problems as possible (Taconis et al. 2001), and also by analyzing worked examples from chosen reference books (Tuovinen \& Sweller 1999).

Previous research has found that the application of this method in T\&L produces positive effects on student achievement and student skills in problem-solving (Razak 2007, Adesoji 2008, Sakorn Pimta 2009 and Sri Adelila et al. 2010). According to Mohd. Johan (2002), a high level of problem-solving skills is required to successfully solve problems and in order to master these skills; students must use the strategies often. Bransford \& Stein (1993) explained that a student's academic achievement can be improved if he masters problem-solving strategies. A research performed by Kadir (2005) found that the implementation of problem-solving strategies in T\&L can improve the results of learning, especially in increasing knowledge, understanding, application, and also achievement. According to Effandi et al. (2007), students must be given the chance to utilize the knowledge, concepts, and skills that they have learnt in solving new problems; after all, students will be able to solve problems well if they are allowed to master and understand concepts as well as use the knowledge that they have gained (Foster 2000). Therefore, emphasizing the implementation of problem-solving strategies in ED T\&L is a step towards transforming the way students learn ED. Though not all topics in ED can be taught using the problem-solving method, it is certain that positive learning outcomes can be produced.

\section{Problem Statement}

ED is a graphic communication language which uses graphic shapes to convey information simply and directly; it has its own rules that are made up of established conventions, symbols, and standards. It was introduced as a subject with the intention of equipping students with the necessary information, basic principles, and practical skills in the field of engineering. The syllabus provided in Malaysian secondary schools focuses on imparting 
concept understanding, basic principles of graphic construction in ED, and also drawing, planning, and reading skills in ED. It is a complicated subject to teach as it involves students, teachers, school administration etc. (BKTV 2003). ED was introduced in Malaysia under the Integrated Secondary School Curriculum in 1994 (KBSM, 1994) which means that this subject has been taught in Malaysia for more than 17 years. It was introduced with the objective to give students early exposure to technical subjects on a basic level before they pursue engineering subjects at the tertiary level (BPTV, 2003). Usually, students' success levels are measured through examinations; according to an analysis of student performance in the ED subject for SPM from year 2003 to 2008 (Lilia et al. 2012), student performance was not excellent in terms of quality even though there was an increase in terms of quantity. This shows that there is a setback in the implementation of the ED subject in school, especially problems faced by both students and teachers with regards to the T\&L process. According to Marc (2009), the challenge in the T\&L of engineering subjects is very real; more often than not, students' learning outcomes do not reach the required objectives and this makes it difficult to ensure that all students master the subject (Marc 2009). Sometimes, students require various approaches that are specific to the type of learning that is being conducted. Therefore, the T\&L of ED at schools must be conducted using the appropriate method in order to make the T\&L efficient and effective.

According to the researchers' earlier study and other past studies, the main problem faced by students in the learning of the ED subject is that they are unable to master the basic concepts of Geometric Drawing (GD) in ED and are not skilled at solving problems in ED (Azizi et al. 2000; Zol Bahri 2001; LPM 2004; Abdul Hadi 2005; BPPDP 2006; Mohd Safarin 2008; Marc 2009; Azaman 2009, 2010). Generally, the learning of ED requires high imagination, creative thinking, and observation and inquiry skills. Students are required to understand and master many basic GD concepts; the mastery of diagram construction in ED is extremely important as failure to master basic GD concepts will subsequently cause failure to understand, interpret, and solve other ED problems (Mohd Safarin, 2008). According to Johari (2005), a deep understanding of concepts is the pre-requirement for mastering the subject. Without a clear understanding of a concept or a basic skill taught at the early stages of learning, the subsequent learning processes will be hindered and difficult (Sabri et al. 2006; Anjali 2010). A student who does not fully understand a concept cannot accurately explain a phenomenon (Wan Zah, 2000). Based on this problem, the researchers took the initiative to implement problem-solving strategies in the T\&L of ED by developing an ED T\&L Module which integrates problem-solving strategies. The researchers have also identified the plane geometrical drawing topic in ED which students experience the most difficulty with i.e. Tangent, Ellipse and Parabolic (TEP). This module was developed in two forms: a printed module and a computer-animated module. Both media consist of the same content and are used in tandem in the T\&L of problem-solving strategies in the classroom. Students and teachers rated high on the module when the feasibility study was carried out (Lilia et al. 2012). Therefore the aim of the paper is to present the discussion on the effects of the implementation of problem-solving strategies on student achievement, student mastery of problem-solving knowledge, and students' ED problem-solving skills through the implementation of the ED T\&L Module.

\section{Conceptual Framework}

The ED T\&L Module is an ED T\&L support material used as a tool to implement problem-solving strategies in ED. It was developed in a systematic and planned manner, grounded in constructivism theory, cognitive load theory, and the application of problem-solving strategies. Diagram 2 shows the conceptual framework used in this research. 
ED T \&L MODULE

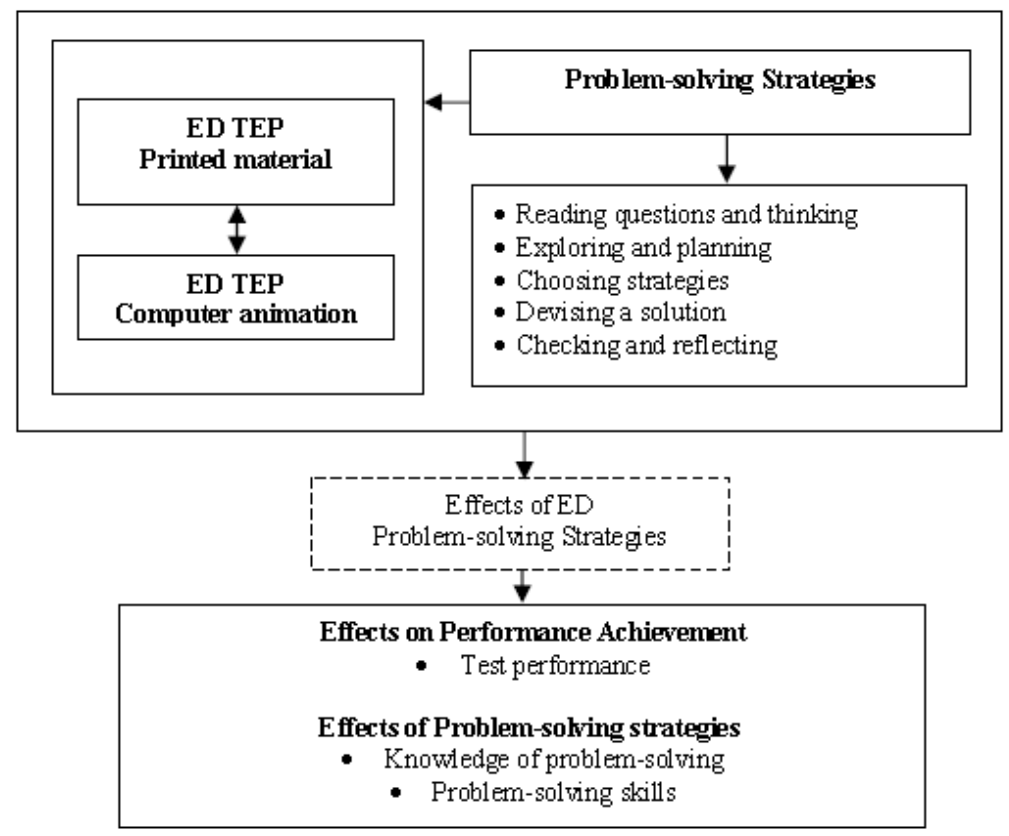

Figure 1.

From the perspective of constructivism (PPK 2001), learning is seen as a process in which students actively construct meaning from new experiences and link it to their existing knowledge. Thus, the activities in the ED T\&L Module are arranged in such a way that encourages students to construct their own meaning through their existing knowledge and also their new experiences. The module also includes a lot of graphics and text. The cognitive load theory was applied as a guide for the arrangement of graphics and texts in order to lessen students' cognitive load. Besides that, computer animations were also used to lessen the cognitive load, especially in the explanation of the concepts required in the construction of ED diagram construction. The computer animation was specifically developed to show how ED concept diagrams are constructed and also the use of problem-solving strategies in ED; this helps students understand the processes that they have to go through when constructing ED diagrams and also the methods of solving problems in ED. According to Marc (2009), Kamariah et al. (2010) and Brandusa et al. (2010), the use of animation can help students better understand and focus on the information being conveyed; it can even help students who face learning problems, especially in terms of learning abstract concepts (Marzia Pisciotta et al. 2010; Anjali 2010). Besides that, computer animation can help students understand the process of problem-solving (Ana 2010) and to imagine the concepts being explained through the transformations shown on screen (Kamariah et al. 2010). Additionally, Oguz (2011) explained that computer-based teaching of problem-solving strategies may improve student achievement and increase students' problem-solving skills.

The ED T\&L Module developed in this research also integrates problem-solving strategies with the objective of improving student mastery of problem-solving knowledge and problem-solving skills in ED. A problem-solving guide was also developed for students where they are exposed to problem-solving strategies and then are required to use the strategies to solve given problems. They are also provided with an example of how problem-solving strategies are used and an ED problem-solving worksheet to assist in solving the problems given to them. The learning strategy of problem-solving used in the development of the ED T\&L Module was based on a model introduced by Krulik and Rudnick (1996) which suggests five steps towards problem-solving. This model was chosen as it appropriate framed the problem-solving steps needed in ED.

The five-step problem-solving model suggested by Krulik and Rudnick (1996) is as follows:

1) Reading the question and thinking:

Student must read the question and identify what is required by the question, examine the diagram, and think of a solution. In this phase, student should observe the design of the given diagram.

\section{2) Exploring and planning:}

Exploring means that the student must examine the design pattern of the given diagram. Identify the tangent 
concepts that are used. Identify the location of the three main circles which shape the tangent diagram. Identify the tangent line and tangent arc, and also the location of main tangent points. Then, the student must find and choose an appropriate answer; for questions that require it, students must plan on how to draw the correct diagram.

\section{3) Choosing a strategy:}

Student should arrange the steps involved in the solution according to priority. This is important due to time constraints. The steps include deciding the diagrams that need to be drawn and which geometric methods should be employed. In this phase, student's mastery of tangent construction concepts is vital in order to identify the best strategy in solving the ED problem.

\section{4) Devising a solution:}

Student must execute the planned strategy and implement the steps needed in the drawing of the diagrams. He has to use geometric methods when constructing the diagrams. He must also possess knowledge on how to use types of lines e.g. construction lines and object lines. He should ensure that he labels the loci of tangent points.

\section{5) Checking and reflecting:}

Student must check his answers and ascertain that each answer fulfills the requirements given by the question. In this phase, student must make sure that only the required objects are drawn using object lines and that the others are drawn using construction lines. He must also ascertain that all measurements are correctly measured and drawn. Every diagram must be drawn using geometric method and a normal line should be drawn in order to identify the loci of tangent points.

In this research, Krulik and Rudnick's (1996) problem-solving model was used as a reference for the implementation of ED problem-solving activities for students. One of the advantages of this model compared to other models is that it includes the exploring and planning strategy. In order to solve problems in ED, students must explore the diagram question given and plan on how to solve it by planning a strategy. The researcher adapted this model to the needs of problem-solving in ED. This model will be used by teachers and students during ED T\&L in solving ED problems. Diagram 2 shows the ED TEP Problem-solving Model adapted from Krulik and Rudnick (1996).

\section{ED TEP Problem-solving Model}

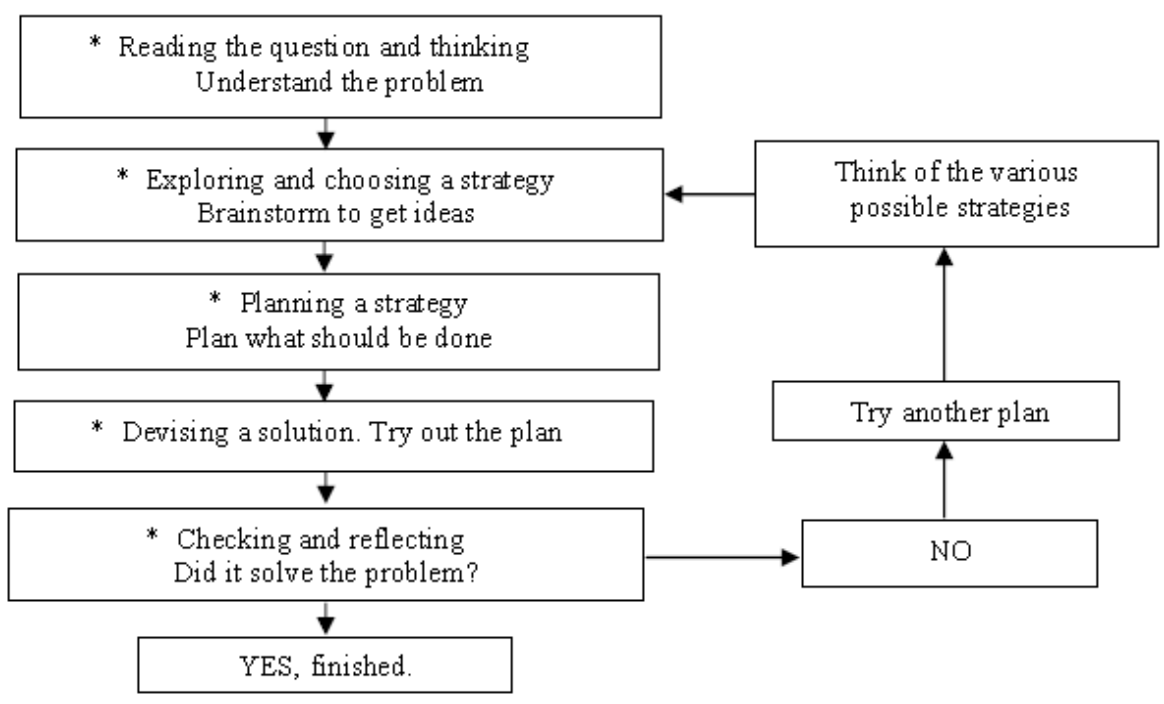

Figure 2. ED TEP Problem-solving model adapted from Krulik and Rudnick (1996) 
The following is an example of how to complete a graphic ED assignment illustrated using computer animation:
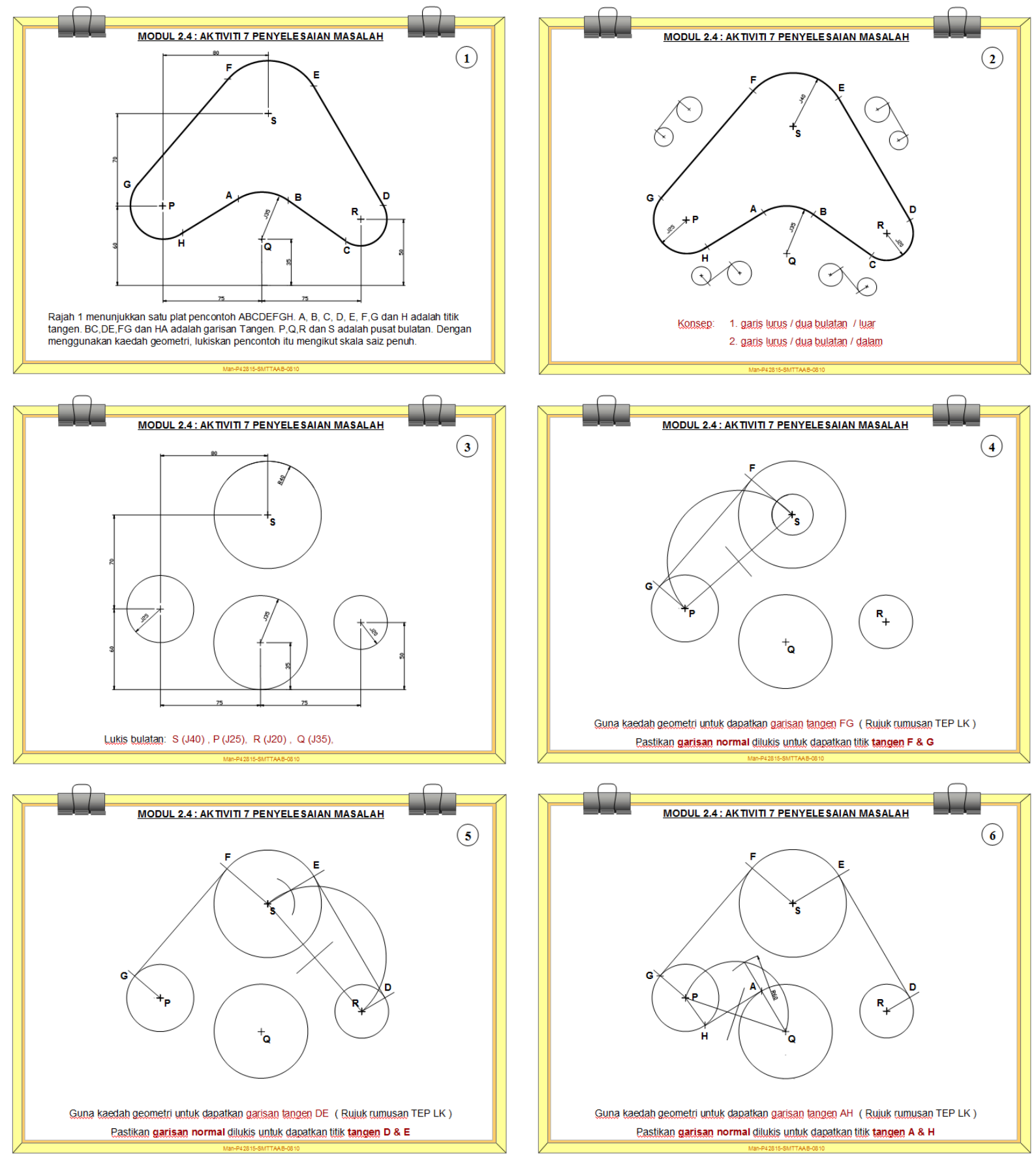

Figure 3. 
The following is a problem-solving worksheet developed for students used as an aid in solving ED problems:

Table 1. Problem solving sheet

\begin{tabular}{llcc}
\hline & STEP ONE: READING AND UNDERSTANDING THE QUESTION & Yes & No \\
\hline 1 & Reading the question & $/$ \\
2 & Understanding the question & $/$ \\
3 & Obtaining information from the tangent question and diagram & $/$ \\
& STEP TWO: a. EXPLORING & Yes & No \\
1 & Reading the question diagram \\
2 & Determining the location of the tangent points \\
3 & Locating the positions of the three main circles \\
4 & Finding the tangent, eclipse, and parabola concepts that are being used: \\
& $\begin{array}{l}\text { a. Identifying the construction method of a straight line with a tangent with one or two circles, } \\
\text { either internal or external }\end{array}$ \\
b. Identifying the construction method of a circle tangent to two other circles, either internal, & $/$ \\
external, or internal and external & $/$ \\
c. Identifying the method used to draw the Jx or Jy arc & $/$ \\
d. Identifying the method used to draw an Ellipse or Parabola & $/$
\end{tabular}

STEP TWO: b. PLANNING

1 Labeling the tangent concepts used in the question diagram

2 Sketching the concepts used in the question diagram

STEP THREE: PLANNING A STRATEGY

Identifying the answer space in the answer paper

2 Observing whether a starting point or reference point is given

3 If no points are given, plan the centers of the main circles

4 Arranging the types of tangent points that should be dealt with first and the methods of construction that need to be used:

a. Tangent points for straight line tangent to a circle

b. Tangent points between a circle with two other circles

c. Tangent points for Jx or Jy

d. The location of minor axis or major axis for an eclipse, or

e. The location of the peak, height, and width points of a parabola

5 Sketching a,b,c,d,e on the question diagram

6 Choosing the easiest concept to be answered first

STEP FOUR: EXECUTING THE STRATEGY

Correctly measuring the distance between the centers of the main circles

2 Drawing the main circles (using the construction line)

3 Drawing the construction of a straight line tangent to a circle (using the construction line)

4 Drawing the construction of circle tangent to a circle (using the construction line)

5 Drawing the construction of Jx or Jy arc (using the construction line)

6 Drawing the construction of an Ellipse quarter or Parabola half (using the construction line)

7 Drawing the normal line in order to obtain tangent points

8 Labeling the tangent points as required by the question

9 Using the object line to complete the diagram as required by the question

10 Reexamining every step that has been drawn 


\section{STEP FIVE: CHECKING AND REFLECTING}

Ensuring that the distance between the centers of the main circles are labeled correctly as per requirements of the question

2 Ensuring that the method used to obtain the tangent points have been shown correctly and clearly

3 Ensuring that geometric method was used to obtain the tangent points i.e. by constructing a normal line

4 Ensuring that the normal line was drawn in order to obtain the tangent points

5 Marking each of the tangent points with black dots and labeling each point as per required by the question

6 Using the envelope method when drawing the ellipse

7 Using the rectangle method when drawing the parabola

8 Ensuring that the method used to obtain the centre of Jz or Jy was shown and drawn correctly

9 Ensuring that the construction line and object line were used correctly

10 Ensuring that the construction line was used when drawing the construction of the diagram

11 Ensuring that the required diagram is completed with an object line

12 Checking that the drawn product fulfills the requirements of the question

\section{Research Method}

\subsection{Research Design and Sample}

This study employed the quasi-experimental research design because the students involved in the research were taken from existing classes; therefore, a random selection of the research sample could not be done (Johnson \& Christensen 2000). The selection of the sample was determined using two methods: the first is purposive sampling for the selection of schools which possess similar research sample criteria, and secondly, random selection where two Technical Secondary Schools (TSS) were selected from eight shortlisted TSS and then one TSS was randomly chosen to be the experimental group (EG) which consisted of 110 students and the other to be the control group (CG) with 109 students. The independent variable of this research is the teaching method; two methods of ED T\&L were used: ED T\&L Module which integrates the use of problem-solving strategies and the conventional ED T\&L method which utilizes text books and the blackboard. These methods will be compared in order to observe the effects on student learning. The dependent variable in this research consists of student achievement, student knowledge of problem-solving in ED, students' problem-solving skills and ED TEP problem-solving activity practices. The pre-test was conducted to both groups to determine their level of ability before the treatment. The result showed that there was no significant different in their ability before the treatment. The treatment was conducted for eight weeks and pos-test was conducted to the the experimental and control groups after the eight week lesson.

\subsection{Instrument}

The two types of instruments employed in this research are the ED performance test and a questionnaire. Student achievement and levels of knowledge are measured using the ED performance test, while students' problem-solving skills were measured using a 5-scale Likert questionnaire. A pilot test and pre-test were carried out on the ED performance test in order to determine its reliability and validity; the reliability was found to be between 0.731 and 0.917 which is a high Alfa Cronbach value. The score from these two instruments were analysed using descriptive statistics and inferential statistics of mean score, standard deviation and independent sample t-test respectively.

\section{Research Findings}

The effects of implementing problem-solving strategies through the use of the ED T\&L Module as support material in T\&L were determined using the ED performance test and the prepared questionnaire. The effects on student achievement and knowledge of problem-solving strategies was determined through an analysis of ED performance tests while students' problem-solving skills and activity practices were determined using the prepared questionnaire.

Descriptive analyses i.e. mean scores and standard deviations of the three dependent variables are shown in Table 2: 
Table 2. Mean score and standard deviation of dependent variables

\begin{tabular}{lcccc}
\hline \multirow{2}{*}{ Dependent variables } & \multicolumn{3}{c}{ Mean and standard deviation } \\
\cline { 2 - 5 } & \multicolumn{2}{c}{ Experimental Group (EG) } & \multicolumn{2}{c}{ Control Group (CG) } \\
& \multicolumn{2}{c}{$\mathrm{N}=110$} & $\mathrm{~N}=109$ & $\mathrm{Sean}$ \\
1. ED Performance Test & Mean & S.D & 53.16 & 17.12 \\
2. Knowledge of TEP Problem-solving & 63.17 & 21.31 & 25.23 & 8.02 \\
3. Problem-solving skills & 30.00 & 10.12 & 3.89 & 0.47 \\
\hline
\end{tabular}

According to Table 2, research findings show that the experimental group's mean score for the ED performance test is 63.17 while the control group's is 53.16 , demonstrating that the experimental group's results are better than the control group's. In terms of students' mastery level of problem-solving knowledge, the mean score for the experimental group is 30.00 while the control group's is 25.25 , again showing that the experimental group's score is better than the control group's. The trend continues for students' problem-solving skills where the experimental group's mean score was 3.93 which is better than the control group's mean score of 3.89. Inferential statistics analysis i.e. independent sample t-test was used to determine whether there is any significant difference in terms of dependent variables between the two groups.

The results of the independent sample t-test statistical analysis are as follows:

\subsection{Effects on Student ED Performance}

The findings of the independent sample t-test analysis on the ED performance test are shown in Table 3:

Table 3. Independent sample t-test analysis on ED Performance test according to group

\begin{tabular}{lccccccc}
\hline Performance test & Group & No. & Mean & S.D & T-value & df & Sig. \\
\hline \multirow{2}{*}{ ED performance test } & EG & 110 & 63.17 & 21.31 & 3.927 & 208.2 & $0.000^{*}$ \\
& CG & 109 & 53.16 & 17.019 & & & \\
\hline
\end{tabular}

\footnotetext{
* Significant $\mathrm{p}$ level $=0.05$
}

According to Table 3, the findings of the independent sample t-test analysis show that there is a significant difference in terms of mean score in the ED performance test between the two groups. This difference is valued at $\mathrm{t}(208.2)=3.927, \mathrm{p}<0.05$ where the mean score of the experimental group (Mean $=63.17$ ) is higher than the control group's (Mean $=53.16$ ). This means that the experimental group displayed better performance compared to the control group, showing that the implementation of problem-solving strategies through the ED T\&L Module was successful in improving student achievement, especially for the TEP topic.

\subsection{Effects on the Mastery of Problem-solving Knowledge}

Findings of the independent sample t-test analysis on student mastery of problem-solving knowledge are shown in Table 4:

Table 4. Independent sample t-test analysis and mean score of student mastery of problem-solving knowledge according to group

\begin{tabular}{lccccccc}
\hline Dependent variable & Group & No. & Mean & S.D & T-value & Df & Sig. \\
\hline \multirow{2}{*}{ TEP ED Problem-solving Knowledge } & EG & 110 & 30.00 & 10.12 & 3.841 & 207.7 & $0.000^{*}$ \\
& CG & 109 & 25.25 & 8.08 & & & \\
\hline
\end{tabular}

\footnotetext{
* Significant $\mathrm{p}$ level $=0.05$

According to Table 4, findings of the independent sample t-test analysis show that there is a significant difference in terms of the mean score between the groups for student mastery of ED problem-solving knowledge. The difference is valued at $\mathrm{t}(207.7)=3.841, \mathrm{p}<0.05$ where the experimental group's mean score $($ Mean $=30.00)$ is higher than the control group's (Mean $=25.25$ ). This indicates that the mean score of experimental group is better than the control group's, showing that the implementation of problem-solving strategies through the ED T\&L Module was successful in improving student knowledge of problem-solving strategies in ED. Further analysis of effects on problem-solving knowledge are shown in Table 5 which displays the findings of the mean score independent sample t-test analysis on aspects of ED problem-solving knowledge between the experimental
} 
group and control group.

Table 5. Mean score independent sample t-test analysis for aspects of ED problem-solving knowledge according to group

\begin{tabular}{lccccccc}
\hline Dependent variable & Group & No. & Mean & S.d & T-value & df & Sig. \\
\hline \multirow{2}{*}{ Mathematical Knowledge } & EG & 110 & 6.41 & 0.70 & 5.744 & 194.2 & $0.000^{*}$ \\
& CG & 109 & 5.74 & 0.99 & & & \\
Conceptual Knowledge & EG & 110 & 19.80 & 7.38 & 1.782 & 217 & 0.076 \\
& CG & 109 & 18.11 & 6.66 & & & \\
Procedural Knowledge & EG & 110 & 3.80 & 2.74 & 7.771 & 180.4 & $0.000^{*}$ \\
& CG & 109 & 1.41 & 1.67 & & & \\
\hline
\end{tabular}

* Significant $\mathrm{p}$ level $=0.05$

Through further analysis of three aspects of student problem-solving knowledge, findings of the independent sample t-test analysis show that there is a significant mean score difference between the two groups for two of the aspects i.e. mathematical knowledge $(\mathrm{t}(194.2)=5.744, \mathrm{p}<0.05)$ and procedural knowledge $(\mathrm{t}(180.4)=7.771$, $\mathrm{p}<0.05$ ); the mean scores for the EG in terms of both mathematical (EG: Mean=6.41, CG: Mean=5.74) and procedural knowledge (EG: Mean=3.80, CG: mean=1.41) were both better than the CG's. On the other hand, no significant difference $(\mathrm{t}(217)=1.782, \mathrm{p}<0.05)$ was found for the conceptual knowledge aspect as both groups showed similar results (EG: Mean=19.80, CG: Mean=18.11), though it should be noted that the EG shoed a better mean score. These findings show that the implementation of problem-solving strategies in the ED T\&L through the use of the ED T\&L Module has successfully improved student knowledge of problem-solving in ED, especially in terms of mathematical and procedural knowledge besides positively affecting conceptual knowledge.

\subsection{Effects on Students' Problem-solving Skills}

The findings of the independent sample t-test analysis on students' problem-solving skills in ED TEP are shown in table 6. According to Table 5, there is no significant mean score difference in terms of students' problem-solving skills between the EG (Mean=3.93) and the CG (Mean=3.89), as the value is only $\mathrm{t}(217)=0.522$, ( $>0.05$ ). Though there is no statistically significant difference, the mean score of the EG is better than the CG. This shows that the implementation of problem-solving strategies through the ED T\&L Module positively affected students' problem-solving skills and the in-classroom learning of ED.

Table 6. Mean score independent sample t-test analysis for problem-solving skills according to group

\begin{tabular}{lccccccc}
\hline Construct & Group & No. & Mean & S.D & T-value & (df) & Sig. \\
\hline \multirow{2}{*}{ Problem-solving skills } & EG & 110 & 3.93 & 0.44 & 0.552 & 217 & 0.582 \\
& CG & 109 & 3.89 & 0.47 & & & \\
Reading and understanding the question aspect & EG & 110 & 3.92 & 0.463 & -0.366 & 217 & 0.714 \\
& CG & 109 & 3.91 & 0.480 & & & \\
Exploring and planning aspect & EG & 110 & 3.92 & 0.496 & 1.639 & 217 & 0.103 \\
& CG & 109 & 3.80 & 0.550 & & & \\
Planning a strategy aspect & EG & 110 & 3.91 & 0.497 & 1.886 & 217 & 0.061 \\
& CG & 109 & 3.78 & 0.535 & & & \\
Executing a strategy aspect & EG & 110 & 3.95 & 0.485 & -0.519 & 217 & 0.604 \\
& CG & 109 & 3.96 & 0.546 & & & \\
Checking and reflecting aspect & EG & 110 & 3.94 & 0.500 & 0.244 & 217 & 0.807 \\
& CG & 109 & 3.95 & 0.629 & & & \\
\hline
\end{tabular}

* Significant $\mathrm{p}$ level $=0.05$

Through further analysis of five aspects of student problem-solving skills, findings of the independent sample t-test analysis show that there is no significant mean score difference between the two groups for all five aspects 
i.e. reading and understanding aspect $(\mathrm{t}(217)=0.366, \mathrm{p}>0.05)$, exploring and planning aspect $(\mathrm{t}(217)=1.639$, $\mathrm{p}>0.05)$, planning a strategy aspect $(\mathrm{t}(217)=1.886, \mathrm{p}>0.05)$, devising a solution aspect $(\mathrm{t}(217)=0.519, \mathrm{p}>0.05)$ and checking and reflecting aspect $(\mathrm{t}(217)=0.244, \mathrm{p}>0.05)$. However, for the reading and understanding the question aspect (EG: Mean=3.92, CG: Mean=3.91) exploring and planning aspect (EG: Mean=3.92, CG: Mean=3.80) and planning a strategy aspect (EG: Mean=3.91, CG: Mean=3.78), the EG's means core was better than the CG's, while the mean score for the executing a strategy aspect (EG: Mean=3.95, CG: Mean=3.96) and the checking and reflecting aspect (EG: Mean=3.94, CG: Mean=3.95) were found to be almost the same for both EG and CG. Overall, the implementation of problem-solving strategies through the ED T\&L Module positively affected students' problem-solving skills achievement in-classroom learning of ED.

\section{Discussion of Research Findings}

Analysis of the research findings has shown that there is a significant difference in the mean score of student achievement and student mastery of problem-solving knowledge between the two groups, where the experimental group showed higher mean scores than the control group. Though there was no significant mean score difference in terms of student problem-solving skills, the experimental group's mean score was better than the control group's. This shows that the implementation of problem-solving strategies through the ED T\&L Module positively affected student achievement, student mastery of problem-solving knowledge and students' problem-solving skills. The findings of this research are supported by other research, especially those done in the field of science, such as Leonard et al (1996), Kadir (2005), Kaptan \& Korkmaz (2002), Tolga \& Ilhan (2010), and Sri Adila et al. (2010).

Generally, the positive effects of the problem-solving strategies can be attributed to the ED T\&L Module and the use of computer animations in the T\&L process of ED. This shows that the implementation of problem-solving strategies through the ED T\&L Module has successfully improved student achievement and student knowledge of problem-solving strategies, besides positively affecting students' problem-solving skills in ED hence is a valuable addition to the ED classroom's T\&L process. The findings of this research are in agreement with research done by Hairani et al. (2008), Kartini (2008), Jinlu Wu (2009) and Elaine (2010) that show how the usage of modules as a support tool in T\&L can make the learning process and student mastery of concepts easier. This clearly supports the implementation of the ED T\&L Module as a method of effectively and efficiently applying problem-solving strategies in the ED classroom.

Besides that, the usage of computer animation is also an important factor that contributes to the success of the implementation of the problem-solving ED T\&L Module. The research findings show that the use of computer animation has successfully improved student achievement and student mastery of problem-solving knowledge. These findings are supported by past research which show that the usage of animation in T\&L reduces misunderstanding of concepts, effectively integrates information, increases the chances for meaningful learning (Mayes \& Anderson 1992; Kim et al. 2007), increases student understanding of what is being learned (Hegarty 2004; Kim et al. 2007; Céline Schlienger et al. 2007; Hoffler \& Leutner 2007) and produces significant effects on student learning outcomes (M. Iqbal \& Herry 2004; Tang 2005; Roxana et al. 2008; Kemal et al. 2010).

In this research, the computer animation was specifically developed for the explanation of ED concepts by illustrating the concepts step-by-step i.e. the steps needed to construct an ED TEP diagram using geometric method and also other steps needed to solve ED TEP problems. The computer animations were developed to show drawing methods using actual drawing tools. The use of animation allows for information to be imparted to students in a simpler manner as students are able to clearly observe the construction process of an ED diagram from start to finish; they are able to use all their senses in the T\&L process. This allows the students to be more focused, attentive, and fully appreciate the learning process. Indirectly, students' cognitive load will also be decreased which serves to maximize the absorption of input. When this process is allowed to happen, students will be able to gain a deeper understanding of what is being learned. The findings of this research show that the usage of computer animation in the implementation of problem-solving strategies in the ED T\&L process positively affects student learning outcomes and that the computer animation developed for this research can be appropriately used as supporting material in the ED T\&L process, specifically for problem-solving strategies.

Based on the research findings, the following recommendations are presented to the relevant authorities, especially those concerning teachers and students:

1) Teachers should give students more learning activities that incorporate problem-solving strategies in the classroom T\&L process.

2) Students should be exposed to problem-solving strategies so that they will be able to enhance their mastery of problem-solving knowledge and skills. 
3) Teachers should identify students who are able to master problem-solving strategies and those who are not and find a solution to tackle this problem.

4) Teacher trainees at Institutes of Higher Learning and Institutes of Teacher Training should improve their knowledge of T\&L strategy, especially in terms of problem-solving strategies.

5) ED teachers are advised to teach ED concepts by emphasizing on following correct steps and encouraging students to make a habit of checking and reflecting on their work.

\section{Conclusion}

Overall, the implementation of problem-solving strategies through the ED T\&L Module positively affected students' learning outcomes especially in improving student achievement, student mastery of problem-solving knowledge and students' problem-solving skills in ED. This shows that the problem-solving strategies integrated in the ED T\&L Module can be appropriately applied in the T\&L of ED. By following the strategies, students are more systematically assisted and structured which is a very important step in training the novice or beginner before facing a more ill structured problem which normally encountered in the real world situation. It has also been demonstrated that it was possible to integrate knowledge and skills using computer assisted teaching and learning. It therefore seems that the inclusion of problem solving strategies in the Engineering Drawing subject may enhance student capability in problem solving knowledge and skills. The use of computer added in Engineering Drawing and other subject or activities in Engineering Education programmme should be promulgated as widely as possible, because it is certainly clear that any innovative teaching and learning to the existing lecture-centric would always be welcomed in the training of future generation engineers and technologist.

\section{References}

Abdul Hadi Bin Mat Dawi. (2005). Kesan animasi 3D terhadap pembelajaran Lukisan Ortografik di kalangan pelajar Sekolah Menengah. Tesis Ph.D. USM.

Adesoji, F. A. (2008). Managing Students' Attitude towards Science through Problem Solving Instructional Strategy. Department of Teacher Education, University of Ibadan, Nigeri. Anthropologist, 10(1), 21-24.

Ahmad, S., Zainal, T. Z. T., \& Omar, A. (2006). Isu-isu Dalam Pendidikan Matematik. Utusan Publication \& Distributors Sdn.Bhd. KL.

Ali, W. Z. W. (2000). Memahami Pembelajaran. Kuala Lumpur: Utusan Publications \& Distributors Sdn Bhd.

Armour, T. E., Bruno, K., \& Allen, B. A. (1992). Toward an understanding of higher-order thinking among minority students. Psychology in the Schools, 29(3), 273-280. http://dx.doi.org/10.1002/1520-6807(199207)29:3<273::AID-PITS2310290310>3.0.CO;2-G

Arsyad, M. I., \& Sujaini, H. (2004). Pengaruh animasi pada program instruksional pendidikan. Seminar Nasional Aplikasi Teknologi Informasi 2004. Yogyakarta.

Bahagian Pengurusan Pendidikan Teknik dan Vokasional (BPTV). (2003). Maklumat, panduan \& borang permohonan kemasukan ke sekolah Teknik \& Vokasional tahun 2003. Putra Jaya: JPT, KPM.

Bakar, K. A., Ayub, A. F. M., \& Tarmizi, R. A. (2010). Utilization of computer technology inlearning transformation. International Journal Of Education And Information Technologies, 4(2), 91-99.

BPPDP. (2006). Kajian Perlaksanaan Mata Pelajaran Lukisan Kejuruteraan Dan Teknologi Kejuruteraan Di Sekolah Menengah Akademik. Ringkasan Eksekutif Kajian-Kajian, Bahagian Perancangan Dan Penyelidikan Dasar Pendidikan 2000-2004. Putrajaya.

Brandusa, P. R. (2010). Inovative Pedagogical Intervention Strategies and Social Software Technologies in an e-Learning Project Initiated by the University Politehnica of Bucharest (Faculty of Applied Sciences). WSEAS Transactions On Advances In Engineering Education, 7(1), 89-108.

Bransford, J. D., \& Stein, B. S. (1993). The ideal problem solver: a guide for thinking, learning and creativity. Ed.Ke-2. New York: W.H. Freeman \& Co.

Céline, Stéphane Conversy, Stéphane Chatty, Magali Anquetil \& Christophe Mertz. (2007). Improving Users' Comprehension of Changes with Animation and Sound: An Empirical Assessment. Lecture Notes in Computer Science. Vol. 4662, Human-Computer Interaction. Pp: 207-220.

Charles, L., Lester, F., \& O’Daffer, P. (1997). How to evaluate progress in problem solving NCTM. Reston: Virginia. 
Deshpande, A. V. (2010). Use of Educational Technology in Engineering Education - A Computer Assisted Instruction (Multimedia)Package for Engineering Students, WSEAS Transactions On Advances In Engineering Education., 7(8), 245-254.

Doymus, K., Karacop, A., \& Simsek, U. (2010). Effects of jigsaw and animation techniques on students' understanding of concepts and subjects in electrochemistry. Education Tech Research Dev, 58, 671-691. http://dx.doi.org/10.1007/s11423-010-9157-2

ElaineMaria Leite Rangel, Isabel Amélia Costa Mendes, Evelin Capellari Cárnio, Leila Maria Marchi Alves, Simone De Godoy, \& Juliane De Almeida Crispim. (2010). Development, implementation, and assessment of a distance module in endocrine physiology. Advance in Physiology Education, 34, 70-74. http://dx.doi.org/10.1152/advan.00070.2009

Eng, T. H. (2005). Kesan sistem pembelajaran berkomputer matematik berasaskan personaliti serta kemahiran berfikir secara kritis dan kreatif. Tesis Ph.D. UKM.

Felder, R. M. (1988). Learning and teaching styles in engineering education. Engr. Education, 78(7), 674-681.

Foster, T. (2000). The development of students' problem-solving skills from instruction emphasizing qualitative problem-solving. Tesis Ph.D. University of Minnesota.

Gök, T., \& Silay, I. (2010). The Effects of Problem Solving Strategies on Students' Achievement, Attitude and Motivation. Latin-American Journal of Physics Education, 4(1), 7-21. Retrieved from http://www.journal.lapen.org.mx

Halim, L., Yasin, R. M., \& Ishar, A. (2012). CAMED: An Innovative Communication Tool in Teaching Engineering Drawing. WSEAS Transactions on Information Science and Applications. 9(2), 58-67.

Haris, H., \& Meerah, T. S. M. (2008). Pembinaan Modul Pengajaran Pembelajaran Berasaskan Otak Dalam Biologi Dengan Menggunakan Model Reka Bentuk Kurikulum Mengundur. Ringkasan Eksekutif Penyelidikan Siswazah. Jilid 1 No.2. Fakulti Pendidikan, UKM.

Hashim, S., Yaakub, R., \& Ahmad, M. Z. (2007). Pedagogi Strategi Dan Teknik Mengajar Dengan Berkesan. KL: PTS Professional Publishing Sdn.Bhd.

Hegarty, M. (2004). Dynamic visualizations and learning: getting to the difficult questions. Learn Instruction, 14, 343-351. http://dx.doi.org/10.1016/j.learninstruc.2004.06.007

Hoffler, T. N., \& Leutner, D. (2007). Instructional animation versus static pictures: a meta-analysis. Learn Instruction, 17(6), 722-738. http://dx.doi.org/10.1016/j.learninstruc.2007.09.013

İbrahim Bilgin, \& Erol Karakirik. (2005). A computer based problem solving environment in Chemistry. The Turkish Online Journal of Educational Technology, 4(3), 7-11.

Ishar, A., Mustapha, R., \& Shamuddin, S. (2009). Kajian Tinjauan Terhadap Permasalahan Pengajaran Dan Pembelajaran Lukisan Kejuruteraan Menurut Persepsi Guru. Seminar Kebangsaan Pendidikan Teknik Dan Vokasional Kali Ke-3 (TVE09). Fakulti Pendidikan, Universiti Teknologi Malaysia, Skudai Johor.

Ishar, A., Mustapha, R., \& Shamuddin, S. (2010). Kajian Tinjauan Terhadap Permasalahan Pengajaran Dan Pembelajaran Lukisan Kejuruteraan Menurut Persepsi Guru dan Pelajar. $15^{\text {th }}$ International Conference On Education. Institut Pendidikan Sultan Hassanal Bolkiah, Univesiti Brunai Darussalam, Brunei.

Ismail, S. B., \& Atan, A. B. (2010). Aplikasi Pendekatan Penyelesaian masalah Dalam Pengajaran Mata Pelajaran Teknikal Dan Vokasional Di Fakulti Pendidikan UTM. Fakulti Pendidikan, Universiti Teknologi Malaysia.

Johnson, B., \& Christensen, L. (2000). Educational Research. Quantitative and Qualitative Approaches. Boston: Allyn and Bacon.

Jonessen, D., Strobel, J., \& Lee, C. B. (2006). Everyday problem solving in engineering: Lessons for engineering educators. Journal of Engineering Education, 95(2), 139-151.

Kadir. (2005). The influence of Problem Posing Approach to learn Maths Level Results Knowledge, Understanding, Application and Evaluation Metacognition terms of high school students in Jakarta. Journal of Education and Culture, 53, 250.

Kaptan, F., \& Korkmaz, H. (2002). The effects of cooperative problem solving approach on creativity in science course. Journal of Qafqaz, 9,143-150.

Kaur, B. (1997). Difficulties with problem solving in Mathematics. The Mathematics Educator, 2(1), 93-112. 
Kementerian Pelajaran Malaysia. (2004). Integrated Secondary School Curriculum Syllabus for Engineering Drawing Form 4 and 5. Kuala Lumpur: KPM.

Kim, S., Yoon, M., Whang, S.-M., Tversky, B., \& Morrison, J. B. (2007). The effect of animation on comprehension and interest. Journal of Computer Assisted Learning, 23, 260-270. http://dx.doi.org/10.1111/j.1365-2729.2006.00219.x

Krulik, S., \& Rudnick, J. A. (1996). Teaching reasoning and problem solving in junior and senior high school. MA: Boston: Allyn and Bacon.

Lembaga Peperiksaan Malaysia (LPM). (2004-2010). Laporan Peperiksaan SPM 2003-2009. Kementerian Pelajaran Malaysia.

Leonard, W. L., Dufrense, R. J., \& Mestre, J. P. (1996). Using qualitative problem-solving strategies to highlight the role of conceptual knowledge in solving problems. American Journal of Physics, 64(12), 1495-1503. http://dx.doi.org/10.1119/1.18409

Mayer, R. E. (1983). Thinking, problem solving, cognition. NewYork: Freeman.

Mayer, R. E., \& Anderson, R. B. (1992). The instructive animation: helping students build connections between words and pictures in multimedia learning. Journal of Educational Psychology, 84(4), 444-452. http://dx.doi.org/10.1037/0022-0663.84.4.444

Moreno, R., \& Layne, L. O. (2008). Do classroom exemplars promote the application of principles in teacher education? a comparison of videos, animations and narratives. Association for Educational Communications and Technology: Education Tech Research Dev., 56, 449-465. http://dx.doi.org/10.1007/s11423-006-9027-0

Nordin, M. S. (2008). Kaedah pengajaran lukisan kejuruteraan menggunakan pendekatan serentak-pemodelan bongkah 3D untuk meningkatkan kemahiran visualisasi pelajar. Tesis Ph.D. UTM.

Olkun, S. (2003). Making connection: Improving spaitial abilities with engineering drawing activities. International Journal of Mathematics Teachig \& Learning. Retrieved from http://www.ex.ac.uk/cimt/ijmtl/ijabout.htm

Pimta, S., Tayruakham, S., \& Nuangchalerm, P. (2009). Factors influencing mathematic problem-solving ability of sixth grade students. Journal of Social Sciences, 5(4), 381-385.

Pisciotta, M., Vello, B., Bordo, C., \& Morgavi, G. (2010). Robots as learning tools in a vocational school, WSEAS Transactions on Advances in Engineering Education, 7(4), 129-138.

Pusat Perkembangan Kurikulum (PPK). (2001). Pembelajaran secara konstruktivisme. Kuala Lumpur: KPM.

Pusat Perkembangan Kurikulum (PPK). (2003). Kemahiran berfikir dalam pengajaran dan pembelajaran. Kuala Lumpur. Dewan Bahasa \& Pustaka.

Razak Abd Samad Bin Yahya. (2007). Aktiviti penyelesaian masalah fizik di kalangan bakal guru siswazah: Satu Kajian Kes. Tesis Ph.D. UKM.

Razali, Z. B. (2001). Pembelajaran berbantu multimedia: implikasi pembelajaran subjek kejuruteraan mekanikal. KUKUM.

Reif, F. (1981). Teaching problem solving-a scientific approach. The Physics Teacher, 19(5), 310-316. http://dx.doi.org/10.1119/1.2340790

Rosen, M. A. (2009). Engineering Education: Future Trends and Advances, Proceedings of the $6^{\text {th }}$ WSEAS International Conference on Engineering Education. 44-52.

Sari, S. A., Nuramalia, N., \& Erlidawati E. (2010). Comparison of Problem Solving with Problem Posing Learning Models of Student Learning Outcomes in the Concept of the Periodic System. Education Technology and Computer (ICETC), 3, 433-435.

Schoenfeld, A. H. (1985). Mathematical problem solving. Orlando, FL: Academic Press, Inc.

Schoenfeld, A. H. (1994). Reflections on doing and teaching mathematics. In A. Schoenfeld Mathematical thinking and problem solving. Hillsdale, NJ: Erlbaum.

Serap Çalikan, \& Gamze Sezgin Selçuk. (2010). Pre-service teachers' use of self-regulation strategies in physics problem solving: Effects of gender and academic achievement. International Journal of the Physical Sciences, 5(12), 1926-1938. Retrieved from http://www.academicjournals.org 
Serin, O. (2011). The effects of the computer-based instruction on the achievement and problem solving skills of the science and Technology students. The Turkish Online Journal of Educational Technology, 10(1), 183-201. Retrieved from http://www.tojet.net/articles/10119.pdf

Taconis, R., Ferguson-Hessler, M. G. M., \& Broekkamp, H. (2001). Teaching science problem solving: An overview of experimental work. Journal of Research in Science Teaching, 38(4), 442-468. http://dx.doi.org/10.1002/tea.1013

Tan, A. G., \& Lee, K. W. (1999). Psychology for teachers: General problem solving and problem solving in science education. Dlm. Loo, S.P. (pnyt.) Educational Challenges in the New Millenium. Proceedings of the MERAERA Joint Conference.

Tanrere, M. (2008). Environmental problem solving in learning chemistry for high school students. Journal of Applied Sciences in Environmental Sanitation, 3(1), 47-50.

Tolga Gök, \& Ilhan Silay. (2010). Effects of problem-solving strategies teaching on the problem-Solving attitudes of cooperative learning groups in physics education. Journal of Theory and Practice in Education, 4(2), 253-266.

Tuovinen, J. E., \& Sweller, J. (1999). A comparison of cognitive load associated with discovery learning and worked examples. Journal of Educational Psychology, 91, 334-341. http://dx.doi.org/10.1037/0022-0663.91.2.334

Viamonte, A. J. (2010). The Computer in the Mathematics Teaching, WSEAS Transactions On Advances In Engineering Education, 3(3), 24-29.

Weinstein, C. E., \& Mayer, R. E. (1986). The teaching of learning strategies. In M. Wittrock (Ed.), Handbook of research on teaching. New York, NY: Macmillan.

Wu, J. L. (2009). Linking Assessment Questions to a Research Article to Stimulate Self-directed Learning and Develop High-order Cognitive Skills in an Undergraduate Module of Molecular Genetics. CBE, Life Sciences Education. 8, 283-290. http://dx.doi.org/10.1187/cbe.09-06-0040

Yahaya, A., \& Mohammad, R. A. (2000). Penilaian terhadap keberkesanan pelaksanaan program lukisan kejuruteraan dari aspek pengajaran dan pembelajaran. National Seminar in Education. Maktab Perguruan Kota Bharu.

Zakaria, E., Nordin, N. M., \& Ahmad, S. (2007). Trend pengajaran dan pembelajaran matematik. Kuala Lumpur: Penerbit Utusan Publications \& Distributors Sdn. Bhd.

Zakaria, M. J. (2002). Perkaitan antara pendekatan belajar dan kemahiran menyelesaikan masalah dengan keupayaan menyelesai masalah bagi tajuk pecahan. Tesis Dr. Fal. UKM.

Zan, R. (2000). A metacognitive intervention in mathematics at university level. International Journal of Mathematical Education in Science \& Technology, 31(1), 143-150. http://dx.doi.org/10.1080/002073900287462

Zuraimi, J. B. (2005). Mechanical properties of high strength concrete at high temperature loading. Tesis Sarjana. Skudai. UTM. 